\title{
Purpose and Application Peculiarities of Management Accounting in Insurance Companies
}

\author{
Markaryan S.E. a \\ Snetkova T.A. ${ }^{b}$ \\ a, b Kazan Federal University, Institute of Management, Economics and Finance, Kazan, 420008, Russia \\ Email: snetkova@mail.ru
}

\section{Doi:10.5901/mjss.2015.v6n1s3p375}

\section{Abstract}

Organization of a management accounting in insurance companies allows to perform operational and strategic management of insurance business based on elaboration of alternative approaches in ultimate goals achievement. Management accounting is directed at satisfaction of information needs of management in all insurance business areas, including actuarial and investment activity. Centralization of the management accounting system along with the development of single information standards at the level of a parent company leads to significant reduction of the business operations of subsidiaries in favor of sales and client service. Management accounting system of the insurance business may serve as a source of information in terms of financial risks, sales and value management only provided it is developed on multi-criterion principle and is based on modern information technologies.

Keywords: Insurance, management accounting, administrative monitoring, budgeting, costs control.

\section{Introductions}

Insurance activity belongs to one of the most fast growing areas of financial infrastructure of economics, aimed at protection of property interests of enterprises, companies and individuals. The main functions of insurance include the following: supporting of social reproduction continuity, stimulation of scientific and technological progress and concentration of investment resources. All afore named functions correspond with the needs of modern economics and determine the role of insurance as an important factor for development of economics. Under current functioning conditions, the guarantee of insurance companies' success is provided by the management accounting and efficient administrative monitoring, which constitute unified and coherent system and comply with requirements for insurance management [8].

Strategic development of insurance activity in the Russian Federation implies improvement of managerial system in insurance companies. Insurance is the most dynamic business allowing to fulfill nonstandard ideas and to achieve significant results within the short time. Under the influence of macroeconomic trends every insurance company holds to strategies aimed at equilibrium, robustness and long-term profitability of business and gaining of market share in regional segments [7]. Complex approach to high quality client servicing aimed at maximal embracing of client audience providing diversified package of insurance services becomes of higher priority. In this regard regional insurance companies have to develop new products, diversify insurance portfolio, establish a personnel pool, and build up efficiently relationship with clients and partners, as well as with regional authorities.

\section{Method}

Current conditions of insurance market development cause necessity of management accounting introduction for the purposes of managerial decisions making. Management accounting is an integrated information system, the base of which is presented by integration of accounting methods elements and principles of management in order to form management information used for managerial decisions making at all stages of management. Management accounting system is aimed at information support required for managerial decisions mostly connected with assessment of anticipated expenses and incomes $[5,6]$.

Key problems of insurance companies include development of efficient business model of regions management and management expenses reduction (fig.1). 

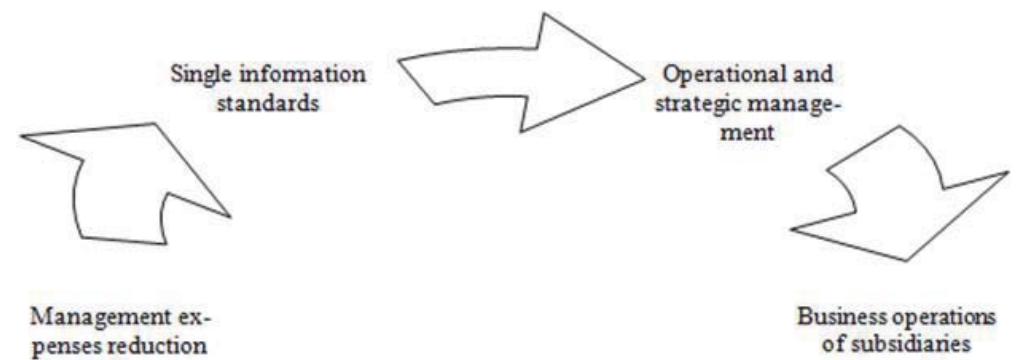
Business operations of subsidiaries

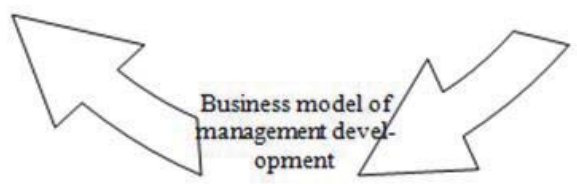

Fig. 1. Key problems of insurance companies

Currently developed model, when the regional subsidiaries of insurance companies perform all management functions, from sales to insurance certificates management and losses settlement, is outdated and fails to express strategic orientation both to upgrading of clients servicing, and introduction of more efficient spending patterns in insurance transactions.

Organization of a management accounting system in the insurance companies allows to exercise operational and strategic management of insurance business based on elaboration of alternative approaches in ultimate goals achieving. Centralization of the management accounting system along with the development of single information standards at the level of a parent company leads to significant reduction of the business operations of subsidiaries in favor of sales and client service. Management accounting is directed to satisfaction of information needs of management in all insurance business areas, including actuarial and investment activity [10].

Management accounting shall not substitute financial accounting, and at the same time management accounting shall not solve the entire problems of the company management. However, informational and analytic base formed in the scope of management accounting forms the basis for management functions realization in the company.

The initial aspects of management accounting development are clear definition of the following system-forming aspects:

- Operative informational and analytic base formation for managerial decisions making;

- A number of methods and tools employment allowing to update information, to provide it in the form suitable for analysis and for calculation of financial and economic indices, required for managerial decisions making;

- Coordination and control of company management and its structural subdivisions, internal document management.

Structure of management accounting organization of insurance companies depends on many factors including type and volume of insurance transactions, organizational structure, system and style of management, advanced system of insurance products sales, insurance activity variety and volume. The diversity of activity types in the insurance company, the related types of expenditures, place of expenditures origin requires application of different approaches to research, detailing, measurement and assessment. Besides, it becomes necessary to collect and consolidate information of different destination for the purposes of planning, forecasting, controlling and one of the alternative decisions making. Insurance company activity represents complex interrelation of business processes resulting in certain insurance type [2].

Insurance products sales and settlement of losses - are bidirectional financial flows. Separation of functional structure and powers of these two essential constituents of the insurer activity - is a generally recognized principle requiring viable motivation mechanism, mutual deterrence and continuous cooperation of managing personnel of insurance company. Administrative monitoring is based on corporate standards system including internal regulation of companies, managing personnel powers and responsibilities system by the relevant management levels.

Control in management accounting differs fundamentally from control functions of accountancy. Business accounting and internal audit in insurance companies are traditionally directed at registration of economic life events aimed at determination of financial results in the insurance company [9]. The management accounting performs control of rationality of insurance activity targets and results selection, monitoring of external and internal limitations in goals achievement, budgetary control of pro forma balance sheets making and execution. 
The management accounting system of insurance business establishes strong interrelations between transaction expenses, indirect costs and insurance services types, and applies current cost accounting methods of certain types of insurance, which facilitate improvement of insurance company costs management efficiency. Costs calculation based on types of insurance activity in the system of balanced indices allows to analyze and improve existing costs structure of the company by the main business processes [11].

\section{Result}

Each type of insurance has its own cost characteristics, and the structure of insurance portfolio determines opportunities of the company in costs reduction in two key directions: cutting of constant general and administrative costs and optimization of variable costs considering behavior of insurance activity volumes. The costs related to payment of claims, settlement of losses under the insurance contract are of special importance in classification of costs by the time of origin [3]. Data on payments of claims in terms of insurance types for previous periods comprise a statistical base for calculation of insurance service price with regard to net premium, value calculation of insurance reserves. Another pricing element of insurance service - a workload - is determined on the basis of management accounting data on transaction costs. At the same time, payments of claims, costs for settlement of losses are the main items of assignable expenses. Calculation of cover amounts allows to conduct a factor analysis of company's final financial results formation in terms of insurance contracts, sales and clients nomenclature, as well as types of insurance.

Under current conditions of insurance companies' operation a special focus should be made on data formation of the insurance services range expanding, provision of competitive abilities on certain types of insurance, certain sectors of insurance market, development and mastering of new insurance services, development of company's branch networks.

It is necessary to develop principal directions of management accounting for the purposes of management data formation.

Such directions of management accounting include the following:

- management accounting of incomes of insurance company in terms of certain types thereof and market sectors;

- management accounting of expenditures of the company by certain types of insurance;

- budgeting of incomes and expenditures of the company, budget administration.

Budgeting is one of the subsystems of management accounting forming the source data, which serves as a basis for managerial decisions on efficient functioning of companies, costs reduction, increase of incomes and finally the intended income gain [1].

\section{Conclusion}

Management accounting system of the insurance business may serve as a source of information in terms of financial risks, sales and value management only provided it is developed on multi-criterion principle and is based on modern information technologies [4]. Application of the outdated IT-solutions failing to cover informational requirements of insurance business management refers to key problems of insurance industry development in modern conditions. Efficiency of managerial decisions making and their fulfillment feasibility serve as basis for insurance activity success.

\section{References}

Chung, H.H., Wynn, J.P. Corporate governance, directors' and officers' insurance premiums and audit fees // Managerial Auditing Journal, 29 (2), 2014. pp: 173-195.

Cummins, J.D., Weiss, M.A. Systemic risk and the U.S. insurance sector // Journal of Risk and Insurance, 81 (3), 2014. pp: $489-527$.

Faure, M.G. The complementary roles of liability, regulation and insurance in safety management: Theory and practice // Journal of Risk Research, 17 (6), 2014. pp: 689-707.

Ismagilova G.N., Safiullin L.N., Bagautdinova N.G. Tourism development in region based on historical heritage. Life Science Journal 2014; 11(6s):363-367.

Klychova G.S., Zakirova A.R., Khametova M.V., Sadrieva E.R. Special aspects of horse husbandry production costs calculation // Mediterranean Journal of Social Sciences vol. 5 № 24, November 2014, pp. 91-97

Friedl, A., Lima de Miranda, K., Schmidt, U. Insurance demand and social comparison: An experimental analysis // Journal of Risk and Uncertainty, 48 (2), 2014. pp: 97-109.

Kaspina, R.G., Shneydman, L.Z. New approach to the oil companies' corporate reporting // Neftyanoe Khozyaistvo - Oil Industry, 9 , 2013. pp: 14-17. 
Markaryan, S.E., Snetkova, T. A., Khairullina, D. V. Administrative aspects of accounting organization. Russian experience and problems // Life Science Journal, 11(8), 2014. pp: 107-111.

Needles Jr., B.E., Shigaev, A., Powers, M., Frigo, M. L. Strategy and integrated financial ratio performance measures: A longitudinal multi-country study of high performance companies // Studies in Managerial and Financial Accounting, 20, 2010. pp: 211-252.

Needles Jr., B.E., Shigaev, A., Powers, M., Frigo, M. L. Operating characteristics of high performance companies: Strategic direction for management // Studies in Managerial and Financial Accounting, 28, 2014. pp: 25-51.

Bagautdinova N.G., Hadiullina G.N., Sarkin A.V., Pratchenko O.V. Typology of the regions with the account of level of influence of infrastructure facilities on the structure of economic areas // Asian Social Science, Volume 10, 28 2014, Pages 57-61.

Sarkin, A.V., Bagautdinova, N.G., Averianov, B.A. Formulation of development strategies of machinery building complex enterprises and estimation of their implementation efficiency // World Applied Sciences Journal, 27(13), 2013, 170-173. 